\title{
Cytokeratin 8, 18 and 19 expressions, epithelial shedding, and stromal extravasation in endometrium of norethisterone enanthate (NET-EN) progestogen contraceptive users
}

\section{(A preliminary report)}

\author{
Sugito Wonodirekso ${ }^{*}$, Wachju Hadisaputra ${ }^{\dagger}$, Biran Affandi ${ }^{\dagger}$, Budiningsih Siregar ${ }^{\ddagger}$, Peter A.W. Rogers ${ }^{\S}$
}

\begin{abstract}
Abstrak
Sitokeratin 8, 18, dan 19 tergolong filamen intermedia (IF) kerangka sel (sitoskeleton) yang terdapat pada setiap epitel selapis. Filamen intermedia berupa struktur intrasitoplasma dinamis yang dapat dipengaruhi oleh sejumlah faktor eksternal. Noretisteron-enantat (NET-EN) yang kontrasepsi progestogen jangka lama telah lama diketahui dapat menghentikan pertumbuhan endometrium tikus. Kontrasepsi progestogen termasuk implant levonorgestrel (LNG, Norplant $(B)$, dan suntikan depomedroksi progesteron asetat (DMPA) serta noretisteron-enantat (NET-EN) menyebabkan perdarahan yang menganggu di antara para akseptornya yang menjadi penyebab lebih dari 50\% kasus batal KB (drop-out) dengan cara ini. Penelitian ini bertujuan untuk mengungkap perubahan pada ekspresi dan distribusi sitokeratin 8, 18, dan 19 epitelium serta perubahan pada stroma dan epitel endometrium akseptor NET-EN dibandingkan dengan endometrium LNG dan endometrium normal. Disajikan 14 biopsi endometrium NET-EN yang dibenam dalam parafin dan dipulas secara rutin menggunakan hematoksilin-eosin (HE) untuk diagnosis fase endometrium dan pengamatan perubahan epitel dan stroma yang terjadi. Selanjutnya jaringan dari blok yang sama dipulas secara imunohistokimia guna melihat perubahan ekspresi dan distribusi sitokeratin yang kemudian dibandingkan dengan jaringan LNG dan normal dari hasil penelitian sebelumnya. Untuk sementara hasilnya memperlihatkan bahwa ekspresi dan distribusi sitokeratin endometrium akseptor NET-EN jangka 3-4 bulan mempunyai gambaran yang bermiripan dengan yang ditemukan pada jaringan endometrium normal. Sebaliknya, ekspresi sitokeratin epitel endometrim LNG sangat berkurang dan sel epitelnya tampak membulat. Ditemukan pula pada pulasan rutin, ekstravasasi dalam stroma subepitel dan lapisan yang lebih dalam, pada akseptor NET-EN. Sayangnya tidak tersedia data yang sama untuk akseptor LNG sehingga tidak dapat dibandingkan. Tidak ditemukan hubungan antara ekspresi sitokeratin dan ekstravasasi stroma dengan pola perdarahan peserta.
\end{abstract}

\begin{abstract}
Cytokeratins 8,18 and 19 are members of the cytoskeletal intermediate filament (IF) family found in all simple epithelia. Intermediate filaments are dynamic intracytoplasmic structures that can be influenced by a number of external factors. Norethisteroneenanthate (NET-EN) is a long-acting progestogen contraceptive that has been found to arrest endometrial growth in the rat. Progestogen contraceptives including levonorgestrel (LNG, Norplant $(B)$ implant, injectable depot-medroxyprogesterone acetate (DMPA) and norethisterone-enanthate (NET-EN) are known to cause bleeding problems among users that are responsible for more than $50 \%$ of the withdrawals from these methods. The aim of this study was to explore any changes in the expression and distribution of epithelial cytokeratin 8, 18 and 19, also changes in endometrial stroma and epithelium in NET-EN users compared to LNG users and normal subjects that could be related to the bleeding problems. Fourteen NET-EN endometrial biopsies were paraffin embedded and stained routinely using hematoxyllin and eosin (HE) for histological dating and observing any stromal and epithelial changes. The slides were then stained immunohisto-chemically to find any changes in the cytokeratin expression and distribution which were then compared with the LNG and normal endometrium from previous study. The results showed that women who had received NET-EN for 3-4 months have a cytokeratin distribution similar to that seen in normal menstrual cycle. This is in contrast to endometrium from LNG users where cytokeratin expression was reduced and the epithelial cells more rounded. In addition, sub-epithelial and deeper stromal extravasations were observed among NET-EN endometrium but no such data available from LNG tissues, thus no comparison can be made. No relationship between cytokeratin expression and stromal extravasations with bleeding patterns were found.
\end{abstract}

Keywords: cytokeratin, endometrium, epithelium, norethisterone enanthate

*Departments of Histology, †Obstetrics and Gynecology, $\ddagger$ Anatomic Pathology, Faculty of Medicine, University of Indonesia, Jakarta, Indonesia, and \$Department of Obstetrics \& Gynecology, Monash University, Melbourne, Australia. 


\section{INTRODUCTION}

Endometrial epithelium contains cytokeratins 8, 18 and 19 that are cytoskeletal intermediate filaments (IFs) of about $10 \mathrm{~mm}$ in diameter. ${ }^{1,2}$ Although the functions of IFs are not yet fully understood, a number of roles have been postulated. In normal epithelial cells, IFs are major constituents of the cytoskeletal network and are meshed around the nucleus with some bundles of IFs being attached to desmosomes and hemidesmosomes via a panoply of putative IF-associated proteins. ${ }^{3}$ Their interactions, directly or indirectly, with the plasma membrane establishes a structural link between the nucleus and the cell surface that has important implications for the organization of the cytoplasm and cellular communication. ${ }^{4,5}$ Cytoskeletal elements are dynamic intracytoplasmic structures that can be affected by external factors. ${ }^{6,7}$ It has also been hypothesized that the IF reorganization observed in cells during pathological situations may be linked, at least in part, to control of growth, either by affecting it, or as a consequence of growth alteration. Other investigators have suggested that loss of cytokeratin reduces mechanical rigidity, thus reducing mechanical strength that may result in reduced basal and lateral cell adhesion. ${ }^{3,9}$ To date very little information has been published about IFs in human endometrial tissue in Norplant and NET-EN acceptors.

As for other progestogen-only contraceptive users, it has been estimated that for the injectable Norethisterone-Enanthate (NET-EN), the one year discontinuation rates for bleeding problems constitute around $50 \%$ or more of all terminations with this method. ${ }^{10}$ Despite increased recent interest in this problem, there is still no basic explanation for the bleeding mechanisms, or consensus on a therapeutic approach for treatment. ${ }^{10}$

NET-EN is widely used throughout the world and is administered intramuscularly. ${ }^{\text {H, } 12,13}$ It has minimal effect on the blood coagulation system. ${ }^{11}$ Chemically, NET-EN is a C-18 steroid belonging to the 19-nortestosterone group (17 ethinyl-17 Beta-heptanoyloxy-4estrene-one) and is dispensed in an oily solvent mixture of benzyl benzoate and castor oil. ${ }^{14}$ NET-EN has been shown to arrest endometrial growth in the rat. $^{15}$

There have been several histological changes observed in endometrium of women receiving long acting progestogeus. It has been reported that women receiving levonorgestrel subdermal implants (Norplant) showed unexpected and significantly increased immunostaining for nuclear progesterone receptors. ${ }^{16}$
Other investigators observed an increase in vascular density and changes in Factor VIII related antigen, ${ }^{17,18}$ and decreased angiogenic activity. ${ }^{19}$ The aim of this study is to observe changes in cytokeratin 8, 18 and 19 expression in endometrial epithelial cells in women receiving NET-EN and compare it with the patterns of expression seen in Norplant users, as reported previously. ${ }^{20}$ In addition, any stromal changes observed in NET-EN tissue will also be evaluated.

\section{METHODS}

\section{Endometrial Biopsy Collection}

Ethical approval for this study was given by The Ethical Commission on Research in Humans of the Faculty of Medicine, University of Indonesia, Jakarta, Indonesia.

The inclusion criteria were: 1) Absence of identifiable endometrial or uterine pathology; 2) No hemostatic or coagulatory disorders reported; 3 ) No hormonal or other therapy received for bleeding problems in the 3 months prior to or during biopsy; 4) Hemoglobin levels above $10 \mathrm{~g} / 100 \mathrm{ml}, 5$ ) a daily menstrual diary, for 90 days (the reference period) prior to endometrial biopsy.

The NET-EN subjects were recruited from Raden Saleh Clinic, Jakarta, Indonesia and had an average age of $32.6 \pm 1.2$ years, (mean \pm SEM). They had all received 2 NET-EN injections (150 $\mathrm{mg}$ norethysterone enanthate) spaced 8 weeks apart, and were 6-8 weeks post the second injection. Endometrial biopsies were taken using a pipelle suction curette (Prodimed, 60530 Neuilly-en-Thele, France) or by microhysteroscopy.

\section{Menstrual Diary Card Analysis}

Based on the daily menstrual diary, bleeding patterns were classified according to WHO definitions as follows; Amenorrhea (no bleeding/spotting days during the reference period), normal/regular bleeding ( 2 to 4 bleeding/spotting episodes per reference period; no bleeding/spotting episode lasting 10 days or more; range of lengths of bleeding/spotting-free intervals of 17 days or less), irregular bleeding (range of length of bleeding/spotting-free intervals greater than 17 days over the reference period), infrequent bleeding (less than 2 bleeding/spotting episodes within the reference period), frequent bleeding (more than 4 bleeding/spotting episodes within the reference period), and 
prolonged bleeding ( 1 or more bleeding/spotting episodes lasting 10 days or more). ${ }^{20}$

\section{Tissue Processing}

Biopsies were fixed in phosphate buffered formalin (phosphate buffer pH 7.4 stock solution, Riedel-de Haën, Germany, and 37\% formalin stock solution, Riedel-de Haën). Biopsies were then embedded in paraffin and $5 \mu \mathrm{m}$ sections cut. Some of the sections were stained routinely using haematoxylin and eosin for histological evaluation by a pathologist. The dating was simply classified as early or late proliferative, early or late secretory-like, atrophic endometrium, or "unclassified" when the sample was inadequate. These classifications were based on the similarities between subject endometrium from the present study and the normal menstrual cycle. However, it is important to note that other histological findings were also recorded, such as stromal extravasation (exv.) or haemorrhage, and or tissue breakdown (tsbr.) in endometrium with proliferative or secretory appearance.

\section{Immunohistochemical Staining}

The procedure followed for immunohistochemistry was similar to that previously published. ${ }^{20}$ Sections were deparaffinized in xylol (E. Merck, Germany) followed by rehydration using graded alcohols through to deionized water. Sections were then washed in 0.1 $M$ phosphate buffered saline (PBS, pH 7.6) and endogenous peroxidase activity was quenched by treatment with $3 \% \mathrm{H}_{2} \mathrm{O}_{2}$ (hydrogen peroxide, BioGenex, USA) for 10 minutes at room temperature. After washing with PBS, tissue antigen was unmasked with $1 \%$ trypsin for 15 minutes at $37^{\circ} \mathrm{C}$ followed by a PBS wash. Primary antibodies to cytokeratin 8,18 and 19 (monoclonal antibody, 5D3, BioGenex, USA) was applied undiluted, direct from the kit, for 15 minutes at $37^{\circ} \mathrm{C}$ to both NET-EN sections and positive controls. For negative controls serum was also applied direct from the kit for 5 minutes at $37^{\circ} \mathrm{C}$. Antibody binding was visualized using chromogen (AEC, BioGenex, USA) consisting of chromogen and substrate. After thorough rinsing with deionized water, mounting media (Entelan, Sigma Chemical Company, USA) was applied, without counter staining, and the sections were coverslipped.

\section{Evaluation of Staining Results}

Results were evaluated semi quantitatively based on staining intensity as follows: 1 = weak staining, 2 = moderate staining, $\mathbf{3}=$ strong staining, and $\mathbf{4}=$ intense staining. Cytokeratin distribution was also observed and classified into: $P N=$ perinuclear cluster (cytokeratin packed around the nucleus), B = basal (cytokeratin distributed mainly in the basal region of the epithelial cells), $\mathrm{A}=$ apical (cytokeratin distributed mainly at the apical region of the epithelial cells), and $\mathrm{B}-\mathrm{A}=$ basal-apical (cytokeratin distributed equally in both apical and basal regions). The classification was based on the majority of cytokeratin distribution seen in each slide since usually there are distribution variations encountered in every individual slide. ${ }^{20}$ Results were compared with those from Norplant users from an earlier study. ${ }^{20}$

\section{RESULTS}

Staining results are summarized in Table 1 . Seven cases of the proliferative and secretory endometrium showed stromal haemorrhage and one of the secretory biopsies also had tissue breakdown. Three cases among them, also of proliferative and secretory endometrium showed no extravasation. As shown in Table 1, none of the subjects were amenorrheic, and there was no correlation between bleeding patterns and the histopathological findings. Regardless of bleeding pattern or histopathological finding, epithelial tissues stained strongly to intensely for cytokeratin, including isolated epithelial fragments from unclassified biopsies. There was variation in cytokeratin distribution among and intra-cases. Sub-epithelial and or deeper extravasation (exv.) and tissue breakdown (tsbr.) were observed (Figure 5) in 7 cases, two of which showed surface epithelium shedding (Figure 6). The last two came from both late proliferative and secretory endometriums of prolonged bleeding patterns. Regardless the bleeding patterns the majority of the cases showed intact endometrial epithelium.

Neither surface nor glandular epithelia showed any marked changes in cell shape. They consisted of a single layer of high columnar cells, with no obvious differences between proliferative or secretory endometrium (Figure 1,2 and 3). By contrast, surface epithelial tissues from Norplant subjects showed weaker immunostaining and epithelial cells were rounded and stratified (Figure 4 ). The 3 secretory and 2 proliferative NET-EN endometrium showed apical cytokeratin distribution, 3 proliferative and 3 secretory endometrium showed basal-apical distribution. The other three biopsies were unclassified due to inadequate tissue samples; 2 of them showed apical distribution and 1 showed apical-basal distribution. 
Table 1. Histopathology, cytokeratins 8,18 and 19 immunohistochemistry results and bleeding patterns of subjects receiving NET-EN contraception

\begin{tabular}{lllllll}
\hline No. & Dating & Score & Distribution & Bleeding patterns & Stromal extravasation & Epithelium \\
\hline 1. & early proliferative & 3 & A & Frequent & exv. & Intact \\
2. & early proliferative & 3 & B-A & Prolonged & none & Intact \\
3. & early proliferative & 4 & A & Prolonged & none & Intact \\
4. & early secretory & 4 & A & Infrequent & exv. Intact $^{\dagger}$ & Intact \\
5. & early secretory & 3 & B-A & Prolonged & exv. + tsbr. & Intact \\
6. & early secretory & 4 & A & Frequent & exv. & Shedding \\
7. & late proliferative & 4 & B-A & Prolonged & exv. & Intact \\
8. & late proliferative & 4 & B-A & Regular & exv. & Shedding \\
9. & late secretory & 4 & A & Prolonged & exv. & Intact \\
10. & late secretory & 4 & B-A & Infrequent & none & Intact \\
11. & late secretory & 4 & B-A & Regular & exv. & Intact \\
12. & unclassified & 4 & B-A & Frequent & - & Intact \\
13. & unclassified & 4 & A & Infrequent & Intact \\
14. & unclassified & 3 & A & Infrequent & & \\
\hline
\end{tabular}

* exv. = extravasation

$\dagger$ tsbr $=$ tissue breakdown

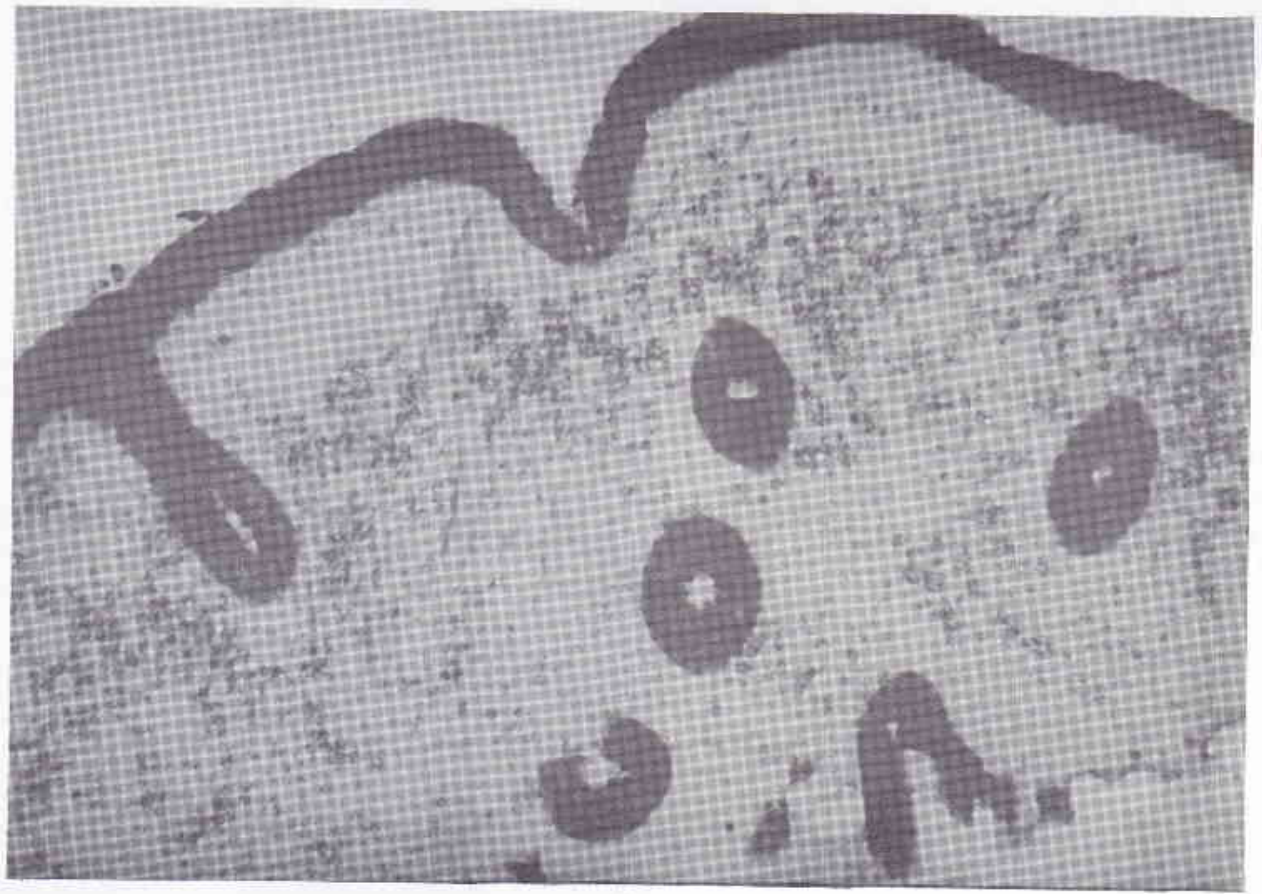

Figure 1. Immunostaining of early proliferative endometrial tissue from a NET-EN user. Note the intense staining and basal-apical distribution of cytokeratin. Epithelial cells are columnar rather than cuboidal or rounded. 


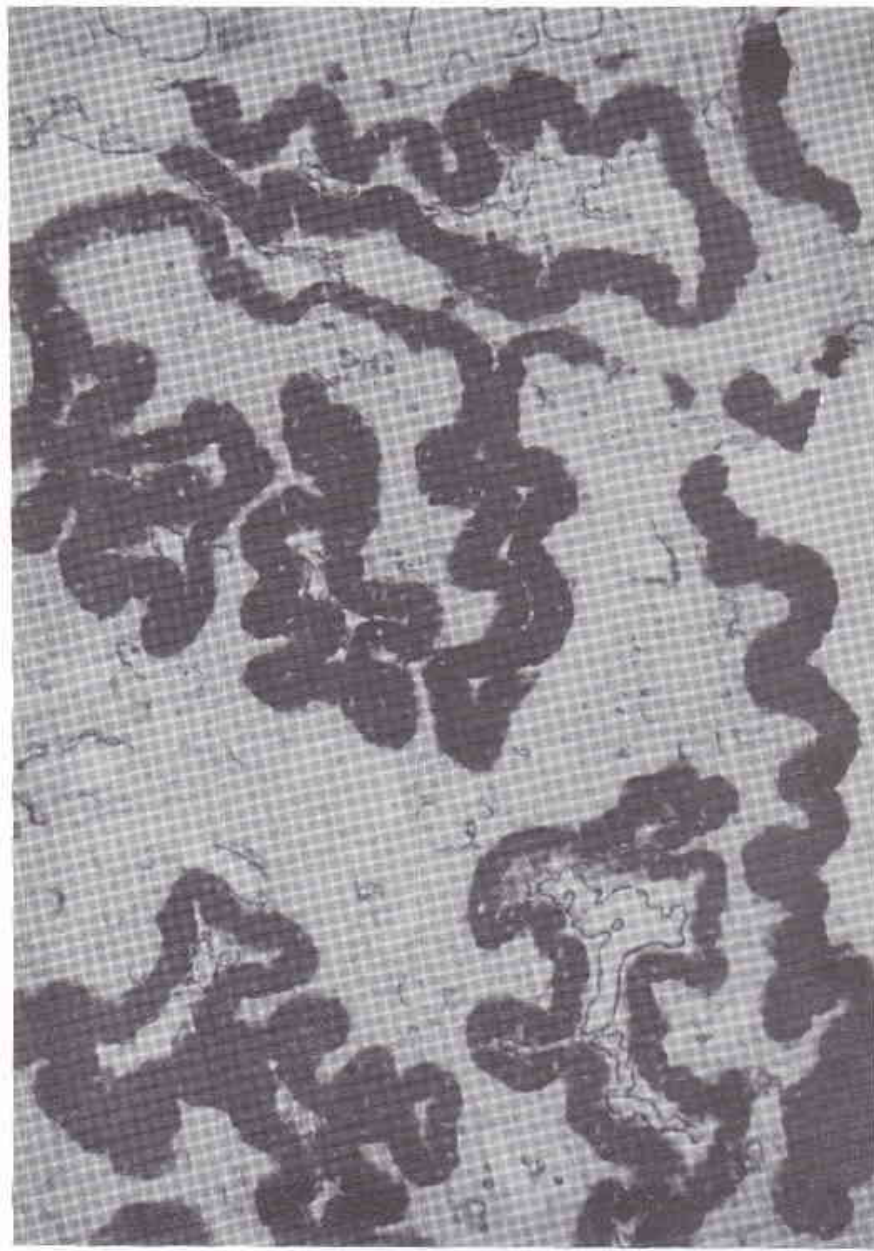

Figure 3. Immunostaining of normal late secretory endometrium tissue. Note the strong-intense staining and the evenly distribution (B-A) of cytokeratin in columnar epithelial cells.
Figure 2. Immunostaining of late secretory endometrial tissue from a NET-EN user. Note the strong-intense staining and distribution of cytokeratin.

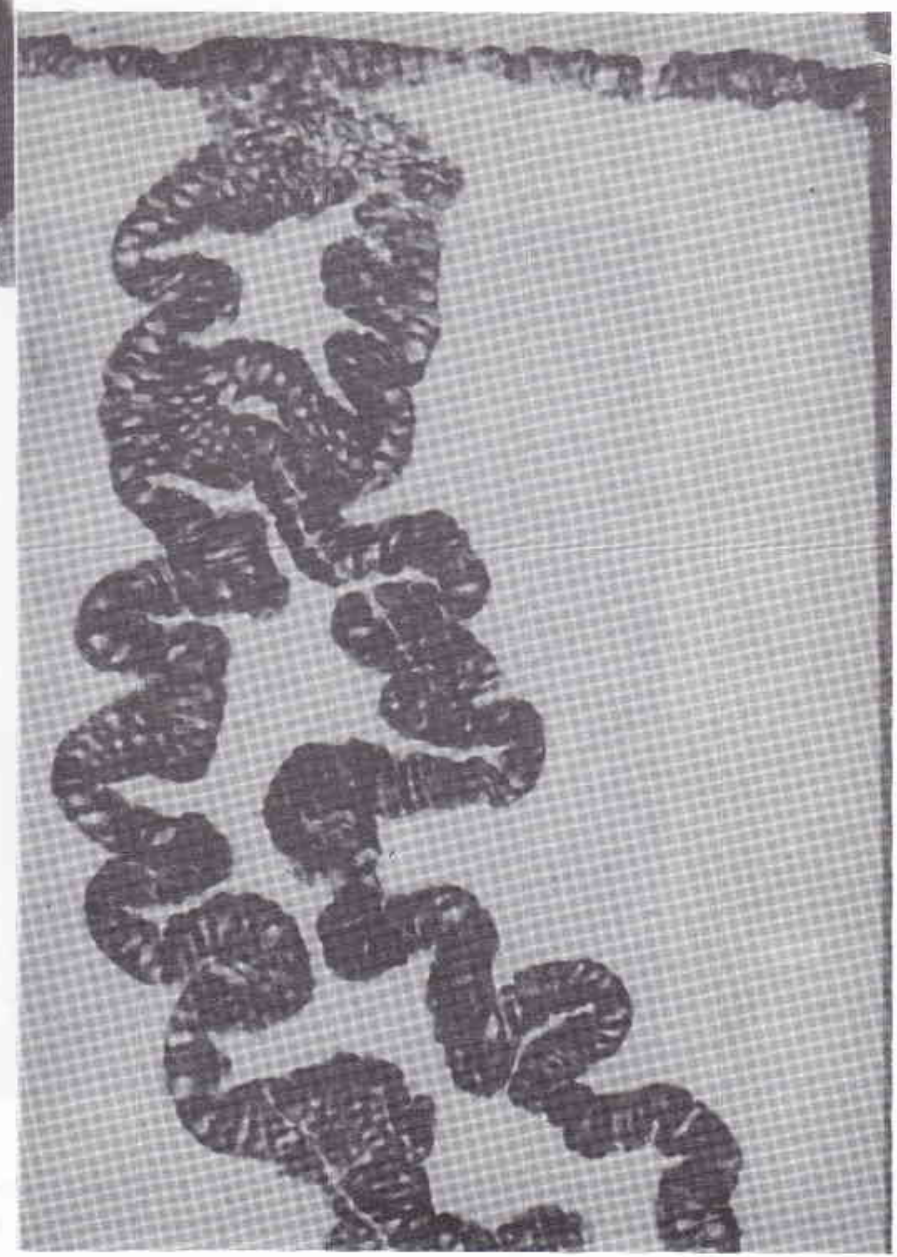




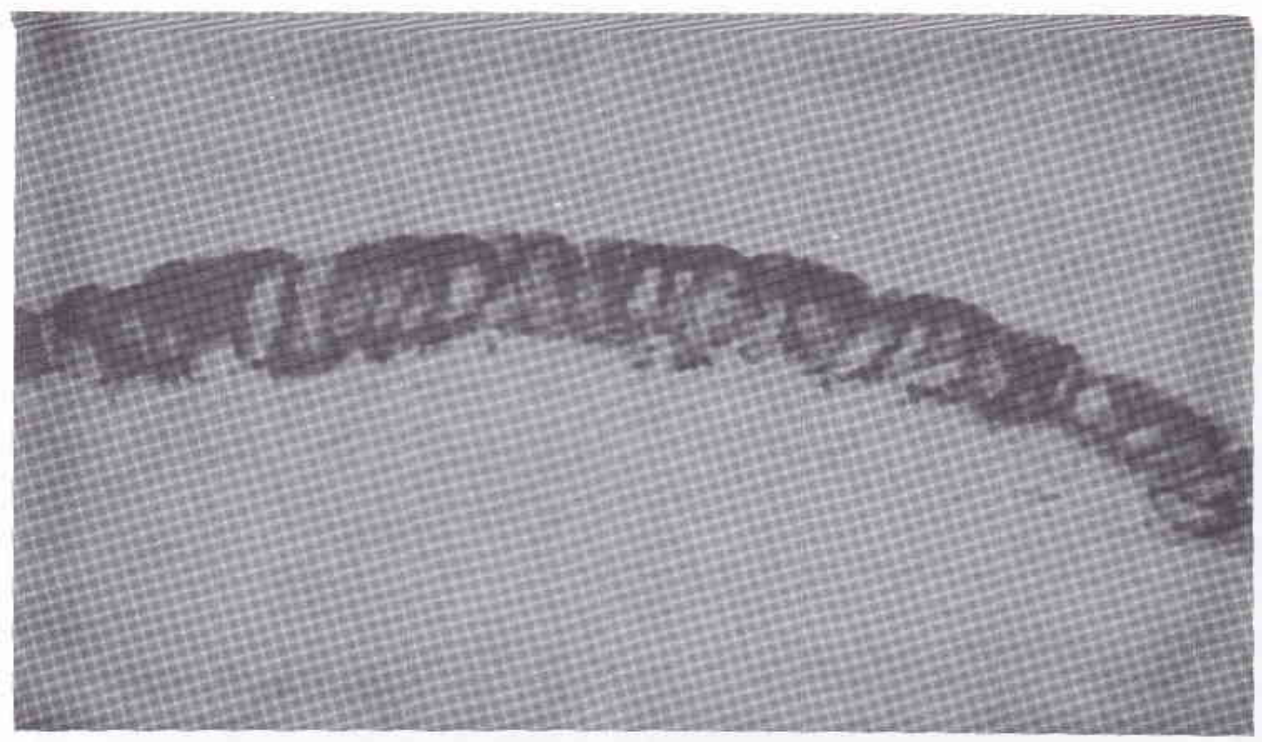

Figure 4. Immunostaining of Norplant tissue. This section contains surface epithelium only, no glandular elements are present. The surface epithelial cells are rounded and appear stratified. Cytokeratin is distributed mainly around the nuclei and overall staining is weaker than that of NET-EN subjects.

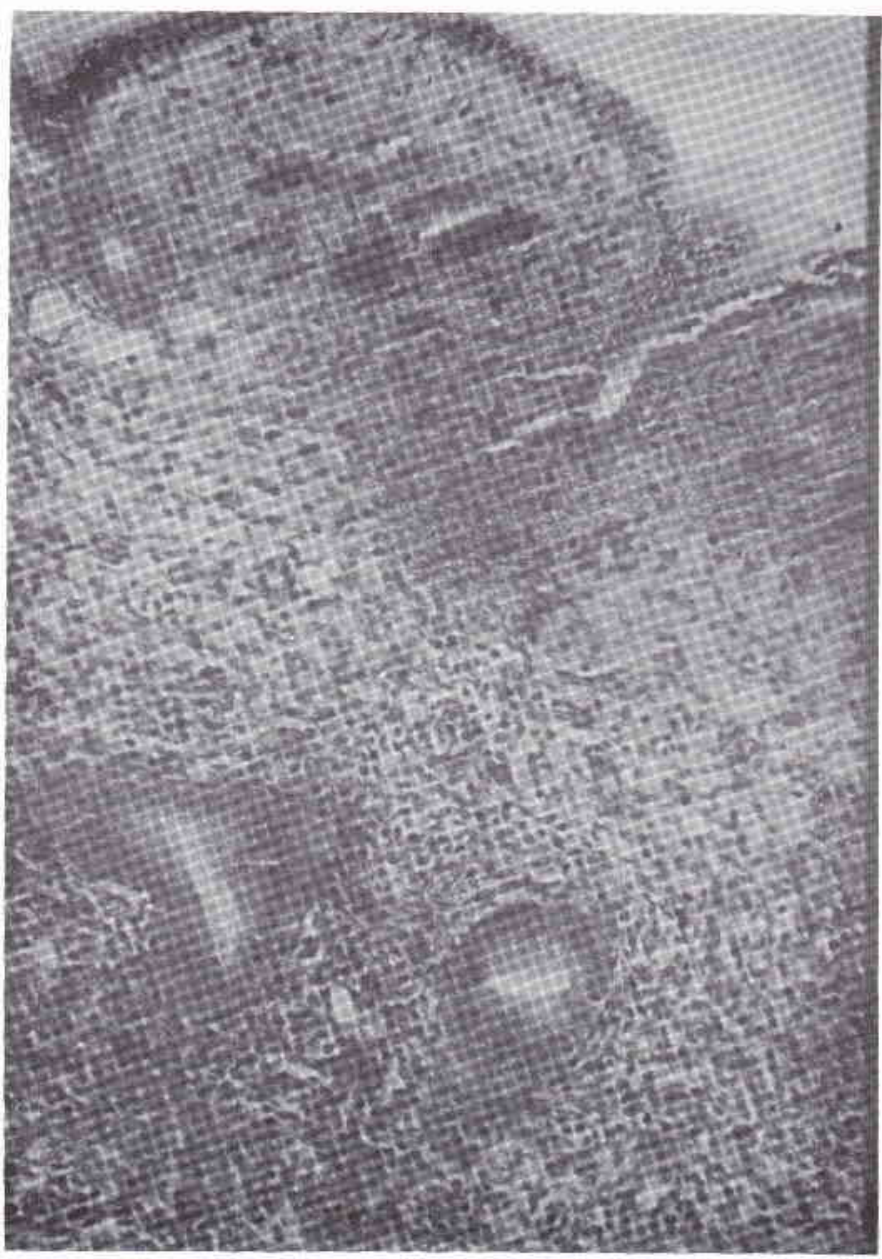

Figure 5. Routine staining of NET-EN tissue showing sub-epithelial and deeper extravasation. 


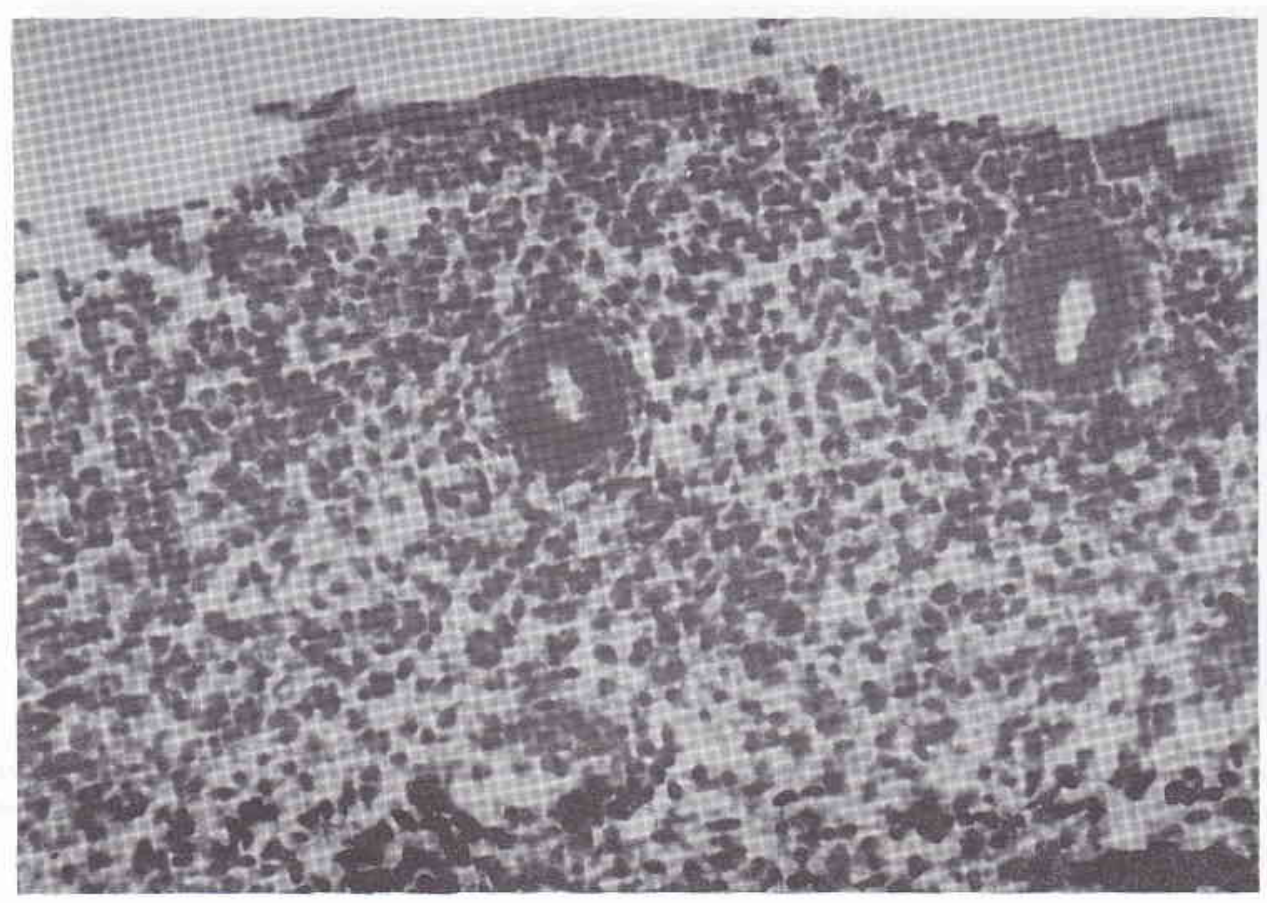

Figure 6. Routine staining of NET-EN tissue showing epithelial shedding and stromal extravasation.

\section{DISCUSSION}

This preliminary results of study on endometrial biopsies from fourteen women who have received NETEN for 3-4 months demonstrates that the expression of intermediate filaments are far more typical of that seen during the normal menstrual cycle, rather than that seen after 3-12 months exposure to levonorgestrel. ${ }^{20}$ Despite the fact that the endometrium from these women was quite varied in its histopathological appearance, the epithelial staining for cytokeratin were always strong. The cellular localization of cytokeratin was equally apical and basal-apical. Since it had been known that cytokeratin were normally distributed around the nucleus, such patterns of distribution could mean as cellular development stage, as long as no cell shape alteration occured. There was no correlation between either menstrual bleeding pattern, or histology, and cytokeratin staining intensity and distribution. Most epithelial cells were columnar in shape, and there was little evidence of regional variability within each endometrial biopsy.

In this stage of study some data were quite confusing. Seven cases showed sub-epithelial or deeper stromal extravasation and two of which showed surface epithelium shedding. The extravasation could mean that the endometrium is of premenstrual-like pattern.
In fact, 4 of them were of secretory endometrium although they consist equally of early- and late secretory endometrium, but three of them were of proliferative endometrium. Apparently there were no correlation, at least at this stage of study, between these findings and the bleeding patterns, since extravasation also occurred in regular and infrequent bleeding patterns as well. All these data could lead to a speculation that epithelial tissue integrity may have important rule in preventing the extravasation to leak out into uterine lumen. Unfortunately no stromal extravasation data were available from the Norplant tissue. The data would be of important information since more than 2 year exposure to progestogen contraceptives will cause bleeding patterns of irregular, regular, and amenorrhea among the majority of users. ${ }^{21}$ These conflicting findings could also be caused by the small sample size and single biopsy inadequacy. In this situation, hysteroscopic evaluation and or larger sample size would be very useful to explain all the findings.

These preliminary results with NET-EN contrast significantly with our previous study looking at cytokeratin in the endometrium of women who had received Norplant for between 3-12 months. In the latter group, cytokeratin expression was significantly reduced, and the epithelial cell appeared cuboidal or 
even rounded in some instances. It is possible that these differences are due to the different lengths of exposure of progestin in the two different groups. Clearly, endometrial biopsies from women who have received NET-EN for longer than 3-4 months will be required to answer this question.

It has been hypothesized that a reduction in epithelial cell cytokeratin content could lead to a loss of mechanical integrity and epithelial cell adhesive properties. ${ }^{3}$ Such alterations in epithelial integrity could lead to increased vulnerability of the endometrium to damage following physical trauma such as uterine contractions, thus resulting in vascular damage and bleeding. However, to date it has not been possible to find any correlation between menstrual bleeding patterns and cytokeratin staining in progestin-only contraceptive users. ${ }^{20}$ Despite this, the integrity of the surface epithelium and glands in the endometrium could easily be an important factor in controlling the escape of extravasated blood from the endometrial tissues into the uterine lumen, and subsequently out through the cervix. Thus, the light spotting and bleeding that its characteristic of progestin-only contraceptive breakthrough bleeding may well be controlled if the epithelial integrity is maintained. Minor vascular ruptures in the sub-epithelial region will more rapidly cease bleeding if the escaped blood is trapped within the endometrial tissues, rather than if it have an avenue of escape into the uterine lumen. The increased intratissue pressure caused by the hematoma will help to stop blood flow quite rapidly, as long as the epithelium is not breached. This hypothesis was supported by the fact that the two cases of epithelial shedding were both of prolonged bleeding patterns. Whether or not epithelial integrity plays a role in stopping blood flow in this manner, require further investigation. However, it has been reported from hysteroscopic studies that sub-epithelial hemorrhage was quite common in the endometrium of women on progestin-only contraception, regardless of the fact of whether or not menstrual bleeding was reported just prior to hysteroscopy. ${ }^{22}$

In interpreting the results from this study, it is important to note the small sample size, and the fact that the primary antibody against cytokeratins 8,18 and 19 used in this study (5D3, BioGenex, USA) was different from that used in our earlier study (NCL-D53, Novocastra, Newcastle, UK). ${ }^{20}$ Despite this, the observations from NET-EN users reported in this study suggest that the epithelium after 2-3 months of exposure is not altered to the same degree as it is in Norplant users. If this observation is confirmed in longer term users of NET-EN, it may be an important difference that could help to resolve the issue of the role of epithelial integrity in reducing the incidence of progestin-only endometrial breakthrough bleeding.

Further studies are planned by using lager sample size which also look at long-term effects of NET-EN, on endometrial cytokeratin. The potential role of epithelial integrity in preventing breakthrough bleeding may provide a new avenue of investigation in the treatment of this problem. In conclusion, results of this study have shown that women who received NET-EN for 3-4 months have an epithelial cytokeratin distribution more similar to that seen during the normal menstrual cycle, although subepithelial and deeper stromal extravasation were observed. This is in contrast to the endometrium from Norplant users where cytokeratin expression is reduced and epithelial cells more rounded. No relationship between cytokeratin expression and breakthrough bleeding pattern is found.

\section{Acknowledgments}

This research was supported by WHO Research and Training Grant No. 92154 to Sugito Wonodirekso. Thanks are due to Nurse Dra Rusminah for patient coordination at Raden Saleh Clinic.

\section{REFFERENCES}

1. Quinlan RA, Schiller DL, Hatzfeld M, Achstätter T, Moll R, Jorcano JL, Magin TM, Franke WW. Pattern of expression and organization of cytokeratin intermediate filaments, Ann NY Acad Sci 1985; 455:282-306.

2. Nagle RB. Intermediate filaments. Am J Clin Pathol (Suppl. 1) $1989 ; 94: \mathrm{S} 14-8$

3. Green KJ, Jones JCR. Interaction of Intermediate Filaments with the Cell Surface. In: Goldman RD and Steinert PM. (eds.). Cellular and Molecular Biology of Intermediate Filaments. New York; Plennum Press,1990; 147-65.

4. Goldman RD, Goldman A, Green K, Jones J, Lieska N, Yang HJ. Intermediate filaments: Possible functions as cytoskeletal connecting links between the nucleus and the cell surface. Ann NY Acad Sci 1985; 455:1-17.

5. Goldman RD, Zackroff RV, Steinert PM. Intermediate filaments: An overview. In Goldman,R.D. and Steinert,P.M. (eds.). Cellular and Molecular Biology of Intermediate filaments. New York: Plenum Press1990; 3-15.

6. Ouhayoun JP, Goffaux JC, Sawaf MH, Shabana AH, Colin C, Forest N. Changes in cytokeratin expression in gingiva during inflammation. J Periodont Res 1990; 25:283-92.

7. Gijbels MJJ, van der Ham F, van Bennekum AM, Roholl PJM. Alteration in cytokeratin expression precedes histological changes in epithelia of vitamin A-deficient rats. Cell Tiss Res1992; 268:197-203. 
8. Skalli $\mathrm{O}$, Gabbiani G. Expression, organisation, and involvement of intermediate filaments in disease processes. In Goldman RD and Steinert PM (eds), Cellular and Molecular Biology of Intermediate Filaments. New York: Plenum Press $1990 ; 415-50$.

9. Tropey N, Wylie CC, Heasman J. Function of maternal cytokeratin in Xenopus development. Nature 1992; 357: 413-5.

10. Odlin V, Fraser IS. Contraception and menstrual bleeding disturbances: A clinical overview. In . D'Arcangues C, Fraser IS, Newton JR, Odlin V, (eds). Contraception and Mechanisms of Endometrial Bleeding. Cambridge: Cambridge University Press, 1990; 5-29.

11. Howard G, Blair M, Chen JK, Fotherby K, Muggeridge J, Elder MJ, Bye,P.G. Clinical trial of norethisterone enanthate (Norigest) injected every two months. Contraception 1982, 25:333-40.

12. Howard G, Blair M, Fotherby K, Elder MG, Bye P. Seven years clinical experience of the injectable contraceptive, norethisterone enanthate. The British Journal of Family Planning 1986; 11:9-16.

13. Joshi JV, Hazari KT, Shah RS, Chada UC, Chitlange S, Gokral JS, Arolkar SG. Serum progesterone and norethisterone levels following injection of norethisterone enanthate in different sites and doses. Steroid 1988; 53:751-61.

14. Topzada M. Norethisterone (Norethindrone) Enanthate, clinical study. In Zatuchni GL, Goldsmith A, Shelton JD, Sciara JJ. (eds.) Long acting Contraceptive Delivery Systems. Philadelphia: Harper and Row, 1983; 502-14.

15. Bowmix T, Mukherjea M. Histological changes in the ovary and uterus of rat after injectable contraceptive therapy. Contraception 1988; 37:529-39.
16. Critchley HOD, Bailey DA, Au CL, Affandi B, Rogers PAW. Immunohistochemical sex steroid receptor distribution in endometrium from long-term subdermal levonorgestrel users and during the normal menstrual cycle. Hum Reprod 1993; 8:1632-39.

17. Rogers PAW, Au CL, Affandi B. Endometrial microvascular density during the normal menstrual cycle and following exposure to long-term levonorgestrel. Hum Reprod 1993; 8:1396-404.

18. Au CL, Affandi B, Rogers PAW. Immunohistochemical staining of von Willebrand factor in the endometrium of women during the first year of Norplant implants use. Contraception 1994, 50:477-489

19. Subakir SB, Hadisaputra W, Siregar B, Santosa DI, Cornain S, Affandi B. Reduced endothelial cell migratory signal production by endometrial explants from women using Norplant contraception. Hum Reprod 1995; 10:2579-83.

20. Wonodirekso S, Au CL, Hadisaputra W, Affandi B, Rogers PAW. Cytokeratin 8,18, and 19 in endometrial epithelial cells during the normal menstrual cycle and in women receiving Norplant. Contraception 1993; 48: 481-93.

21. Shoupe D, Ballagh S, Mishell DR. Bleeding patterns in Norplant Contraceptive Implant Users. In: Alexander NJ, d'Arcangues C, (eds.) Steroid Hormone and Uterine Bleeding. Washington DC, USA, Am Assoc for the Adv Sci 1992; 49-57.

22. Hickey M, Fraser I, Dwarte D, Graham S. Endometria] vasculature in Norplant users: preliminary results from a hysteroscopic study. Hum Reprod 11 suplement 2, 1996, 35-44. 